\title{
Optimal Production Parameters of Water based drilling Mud from Ground nut husk, Trona and Palm Head Sponge Powderas Additives Using Box-Behnken Design
}

\author{
S. I. Ahmed ${ }^{\# 1}$, S. Abdulsalam ${ }^{\# 2}$ and U. Joseph ${ }^{\# 3}$ \\ \#1 Department of Chemical Engineering, Abubakar Tafawa Balewa University Bauchi, \\ Nigeria, +2348131808280, alsaeedng@yahoo.com \\ \#2 Department of Chemical Engineering, Abubakar Tafawa Balewa University Bauchi, \\ Nigeria, +2348032839412, surajudeen_abdulsalam@yahoo.com \\ \#3 Department of Chemical Engineering, Abubakar Tafawa Balewa University Bauchi, \\ Nigeria, +2348034728525, joeyzaza227@yahoo.com
}

\section{ABSTRACT}

Mud additives are always required to provide sufficient hydrostatic pressure to ensure borehole stability. In view of the this, the need to optimize the production of a water-based drilling mud using additives is highly desirable. Design Expert 6.0.8 software was used to carry out the optimization process by employing the surface response approach in the BoxBehnken design. The optimization process was carried out in triplicate for 15 runs. The independent variables were the additives - the pulverized ground nut husk, trona and burnt palm head sponge powder; while the dependent variables were plastic viscosity, yield point, apparent viscosity, $\mathrm{n}$ and $\mathrm{k}$ - factors. Experimental results from the Box-Behnken design revealed that optimal parameters for the independent variables (i.e. trona, pulverized ground nut husk and burnt palm head sponge powder) were found to be $10.0 \mathrm{~g}, 18.58 \mathrm{~g}$ and $5.0 \mathrm{~g}$ respectively and its corresponding rheological properties (i.e. plastic viscosity (PV), yield point (YP), apparent viscosity (AV), n- factor and $\mathrm{k}$ - factor) were $9.26 \mathrm{cP}, 20.0 \mathrm{lbf} / 100 \mathrm{ft}^{2}$, $19.26 \mathrm{cP}, 0.40$ and 16.32 respectively. It can be concluded that, the produced mud, which obeys Bingham plastic fluid model can be used as a standard drilling mud in the petroleum industry.

Key words:Drilling mud, Box-Behnken Design, Ground nut husk, Trona, Palm head sponge.

\section{Corresponding Author:S. I. Ahmed}

\section{INTRODUCTION}

Drilling the wellbore is the first and the most expensive step in the oil and gas industry. Expenditures for drilling represents $25 \%$ of the total oil field exploitation cost and are concentrated mostly in exploration and development of well drilling (Adekile, 2010). Drilling fluids, which represent about $15-18 \%$ of the total cost of petroleum well drilling must generally comply with three important requirements: they should be easy to use, not too expensive and environmentally friendly (Adekile, 2010).

Expected increase in drilling activities has necessitated the search for alternative sources of drilling mud additives, so as to improve its quality to meet some specific needs. Drilling 
fluid additives include weighting materials, viscosifiers, filtration control additives, $\mathrm{pH} /$ alkalinity control chemicals, dispersants, deflocculants, thinners, surfactants, emulsifiers, shale inhibitors, corrosion inhibitors, oxygen scavengers, hydrogen sulfide (H2S) scavengers, lubricants, bridging agents and lost circulation materials (LCMs) (Caenn et al., 2013). The principal functions of drilling fluid are to: control subsurface pressures, maintaining well control, remove drill cuttings from beneath the bit and circulate them to the surface, maintain wellbore stability mechanically and chemically, transmit hydraulic energy to the drill bit and down hole tools, cool and lubricate the drill string and bit (Growcock and Harvey, 2012).

Many authors have conducted research studies related to optimization for the production of water-based drilling mud from specific additives. A few of them include; Optimization for the production of water-based drilling mud from clay (Oyegoke, 2011), Drilling fluid formulation using cellulose generated from groundnut husk (Dagde et al., 2014), Improvement of rheological properties of drilling fluid using (Olatunde et al., 2012), Rheological properties and corrosion characteristics of drilling mud additives (Annudeep, 2012), Modification of drilling fluid $\mathrm{pH}$ with local Nigerian additives by Okorie (2009). However, there is need to look into greener and more sustainable additives and cheaper approaches than those focused on in the above-mentioned studies.

This study therefore aimed at providing optimum production parameters of water-based drilling mud using ground nut husk, trona and palm head sponge powder as additives. The production process was optimized using the Box-Behnken design. Research into this will promote reduction in drilling cost by sourcing for cheap additives, which also leads to the improvement in the quality of the mud produced.

\section{MATERIALS AND METHODS Methods}

The production method of the drilling fluids and the determination of the rheological and allied properties were carried out based on the API drilling mud production standards (API, 2000; Ogbonna, 2010; Joel et al, 2012). The Bentonite (sourced from Mubi, Adamawa State, Nigeria) and Barite materials (sourced from Akwanga in Nasarawa State, Nigeria) were subjected to size reduction by crushing and grinding to a particle size of $85 \mu \mathrm{m}$ and $850 \mu \mathrm{m}$ respectively. The raw materials such as water, bentonite, pulverized ground nut husk, starch, barite, trona and burnt palm head sponge powder in the amounts; $245 \mathrm{ml}, 75.0 \mathrm{~g}, 20.0 \mathrm{~g}, 7.0$ $\mathrm{g}, 30.0 \mathrm{~g}, 30.0 \mathrm{~g}$ and $5.0 \mathrm{~g}$ respectively were measured using the graduated cylinder and electronic weighing balance as shown in Table 1. These raw materials were then poured one after the other, with an interval of $5 \mathrm{~min}$ into the steel cup of the single spindle mixer. The application of the raw materials was carried out as arranged in Table 1. After charging the materials into the mixer steel cup, it was allowed for $30 \mathrm{~min}$, under stirring condition, for complete mixing of the materials, which gave finely formulated water-based drilling mud. Drilling mud balance was used to measure the density of the mud by introducing the drilling mud into the mud balance cup and adjusting the pivot gauge until equilibrium was attained, then reading was recorded from the calibrated meter rule. 
Table 1Materials and their functions

\begin{tabular}{|c|c|c|c|}
\hline Raw material/reagents & Function & Justification & Quantity \\
\hline Water & Base fluid & & $245 \mathrm{ml}$ \\
\hline Pulverized Ground nut husk & $\begin{array}{l}\text { Viscosifier and fluid } \\
\text { loss control agent }\end{array}$ & $\begin{array}{lr}\text { Ground nut } & \text { Husk } \\
\text { was used } & \text { as } \\
\text { substitute } & \text { to } \\
\text { polyionic cellulose, } \\
\text { due to is } \\
\text { availability as } \\
\text { substitute to } \\
\text { Polyionic cellulose } \\
\text { which is imported. }\end{array}$ & $20.0 \mathrm{~g}$ \\
\hline Starch & $\begin{array}{l}\text { Viscosifier and fluid } \\
\text { loss control agent }\end{array}$ & $\begin{array}{l}\text { Starch was used } \\
\text { because of its } \\
\text { availability and } \\
\text { cheapness relative } \\
\text { to other Viscofiers }\end{array}$ & $7.0 \mathrm{~g}$ \\
\hline Barite & Weighting agent & $\begin{array}{l}\text { Barite is available } \\
\text { in commercial } \\
\text { quantity and } \\
\text { doesn't have to be } \\
\text { imported. }\end{array}$ & $30.0 \mathrm{~g}$ \\
\hline Trona (Akanwu)- $\mathrm{K}_{2} \mathrm{CO}_{3}$ & Swelling agent & $\begin{array}{l}\text { Trona was used as } \\
\text { substitute to already } \\
\text { processed Sodium } \\
\text { Carbonate, due to } \\
\text { its availability. }\end{array}$ & $30.0 \mathrm{~g}$ \\
\hline $\begin{array}{l}\text { Burnt palm-head sponge } \\
\text { powder }-\mathrm{NaOH}\end{array}$ & $\mathrm{pH}$ control & $\begin{array}{l}\text { This was used as } \\
\text { substitute to already } \\
\text { processed Sodium } \\
\text { Hydroxide (NaOH). }\end{array}$ & $5.0 \mathrm{~g}$ \\
\hline
\end{tabular}

A Fan viscometer was then used for the measurement of rheological properties of the formulated drilling mud. The equipment was switched on and allowed to stabilize after which the mud sample was poured into the cup of the viscometer and placed on the viscometer stand. The stand was adjusted and held in position as the rotor sleeve was immersed in the mud to fill the line. The speed selector knob was selected to rotate at $600 \mathrm{rpm}$ (revolutions per minute). When a steady dial reading was reached, this was recorded as the 600 RPM dial reading. The above procedure was repeated for $300 \mathrm{rpm}$. The plastic viscosity, yield point, apparent viscosity, $\mathrm{n}$ and $\mathrm{k}$ values were evaluated using Equations (1) - (5). The $\mathrm{pH}$ meter was then used to measure the $\mathrm{pH}$ of the formulated drilling fluids. This procedure was carried out in triplicate, and the Box-Behnken technique was used to optimize the production process. The experimental range and the levels of the independent variable are shown in Table 2.

Plastic viscosity $(P V), c P$

$$
=600 \text { rpm reading }-300 \text { rpm reading }
$$




$$
\begin{aligned}
& \text { Yield point }(Y P),=\frac{l b}{100 \mathrm{ft}^{2}} \\
& =300 \mathrm{rpm} \text { reading }- \text { plastic viscosity }(P V) \\
& \begin{aligned}
\text { Apparent Viscosity }(\mathrm{AV}) \\
=
\end{aligned} \\
& \quad=\frac{600 \mathrm{rpm} \text { reading }}{2} \\
& \begin{array}{l}
n=3.32 \log \frac{\theta_{600}}{\theta_{300}} \\
=\theta_{300}\left(511^{n}\right)
\end{array}
\end{aligned}
$$

\begin{tabular}{|c|c|c|c|}
\hline $\begin{array}{l}\text { Independent } \\
\text { variable }\end{array}$ & Low level & Medium level & High level \\
\hline Code value & $(-1)$ & $(\mathbf{0})$ & $(+1)$ \\
\hline Trona(Akanwu)(g) & 10 & 20 & 30 \\
\hline $\begin{array}{l}\text { Pulverized Ground } \\
\text { nut husk }(\mathrm{g})\end{array}$ & 10 & 15 & 20 \\
\hline $\begin{array}{l}\text { Burnt palm-head } \\
\text { sponge powder }(\mathrm{g})\end{array}$ & 0.0 & 2.5 & 5.0 \\
\hline
\end{tabular}

Table 2Experimental range and the levels of the independent variables

The Design Expert software version 6.0.8 was used to optimize the production process by clicking on start file and "New Design" simultaneously as shown in Figure 1. Then, response surface tab was selected as shown in Figure 2. The Box- Behnken design option was selected thereafter, as shown in Figure 3. On the same window, the "Numeric factors" drop down button was set to "3" as three independent variables were considered; the names and units were entered as Trona, pulverized ground nut husk and burnt palm-head sponge powder, all in grams. The lower and higher limits were set for each independent variable as shown in Figure 4. The next window shows number of responses to be observed. In this case, five responses were studied, which include: plastic viscosity (PV), yield point (YP), apparent viscosity (AV), n-factor and k-factor, as shown in Figures 5. Values obtained from 15 runs of experimental determination were then inserted into the response cells, as shown in Figure 6.

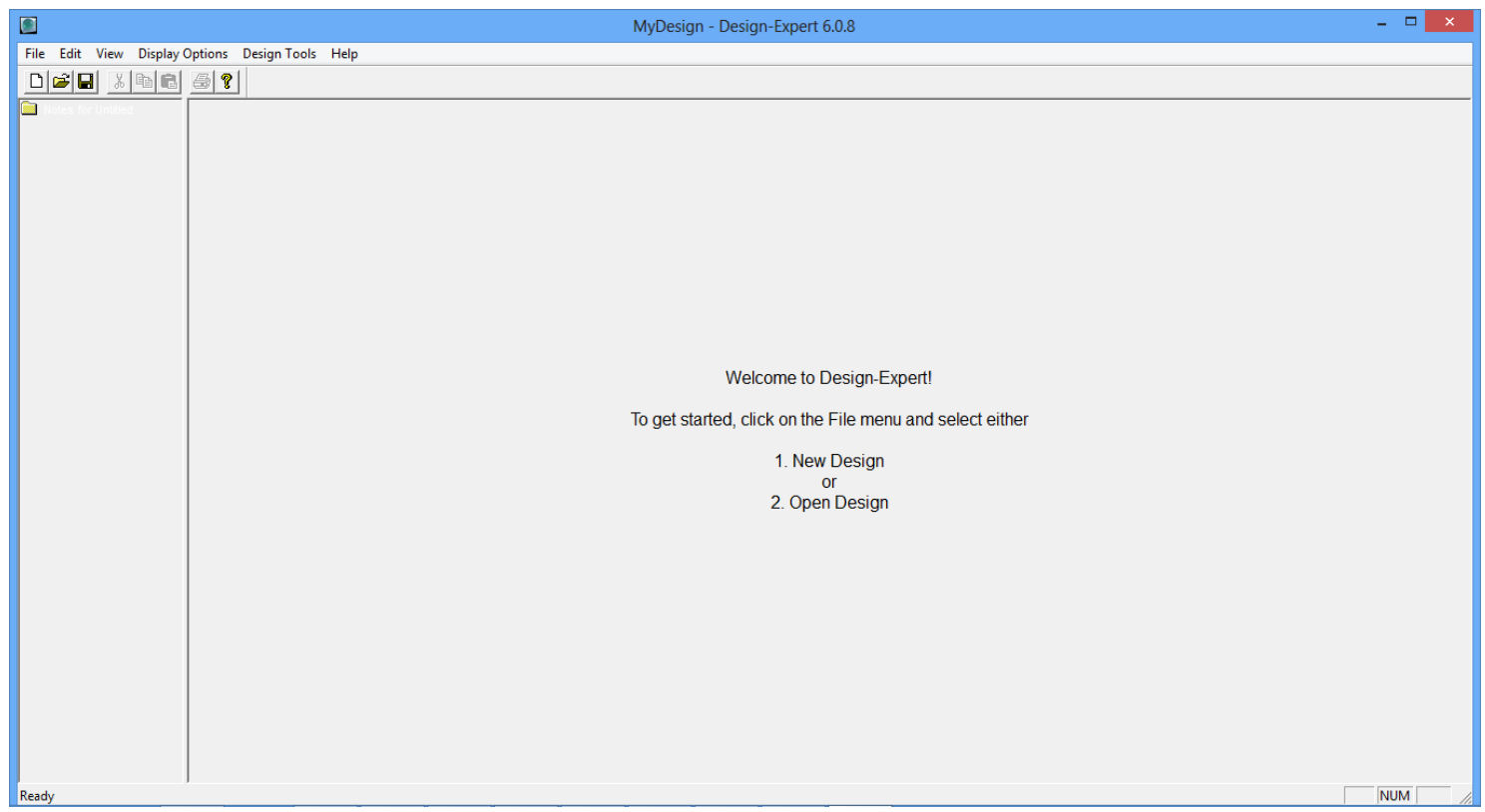

Figure 1.Design-Expert start window 
DOI : https://dx.doi.org/10.26808/rs.ed.i9v3.07

International Journal of Emerging Trends in Engineering and Development

Issue 9, Vol.3(Apr- May 2019)

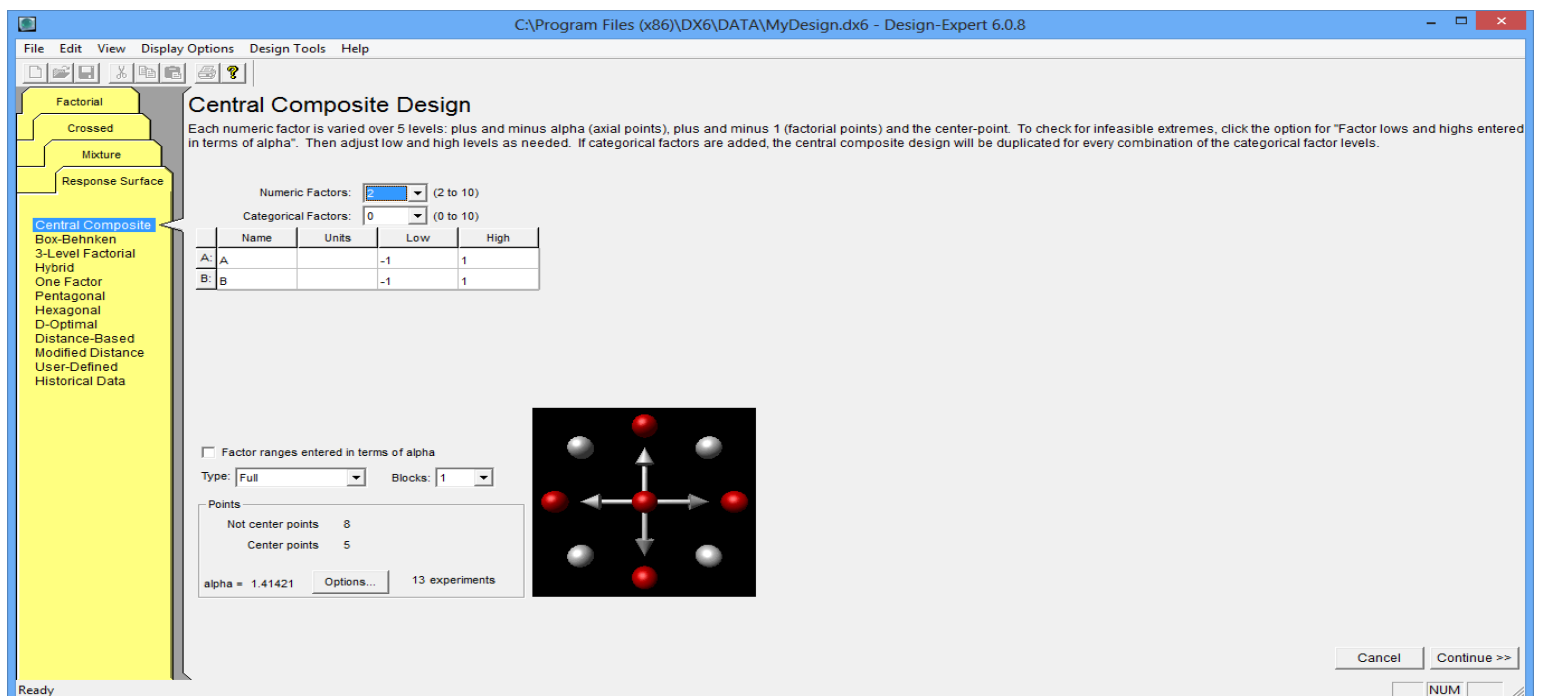

Figure 2. Response surface window

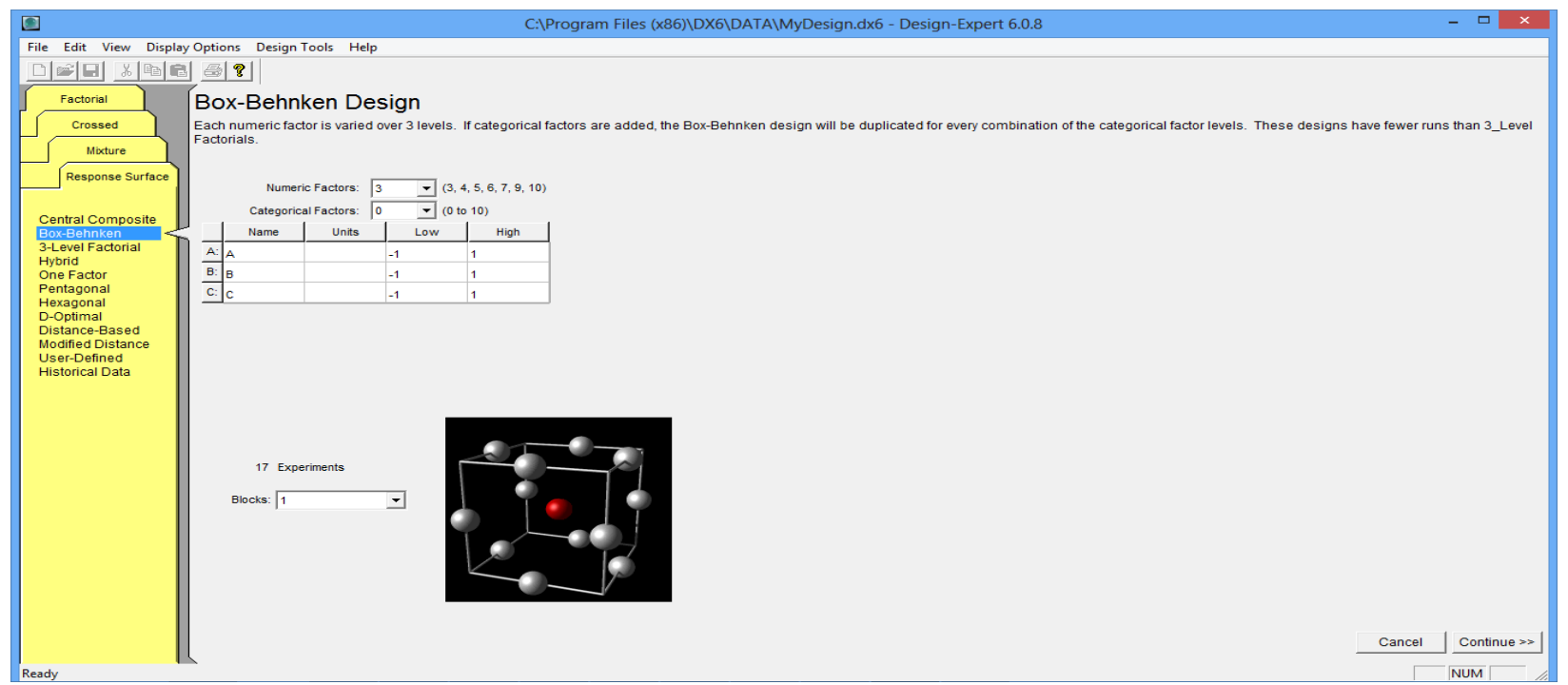

Figure 3.Box-Behnken design window

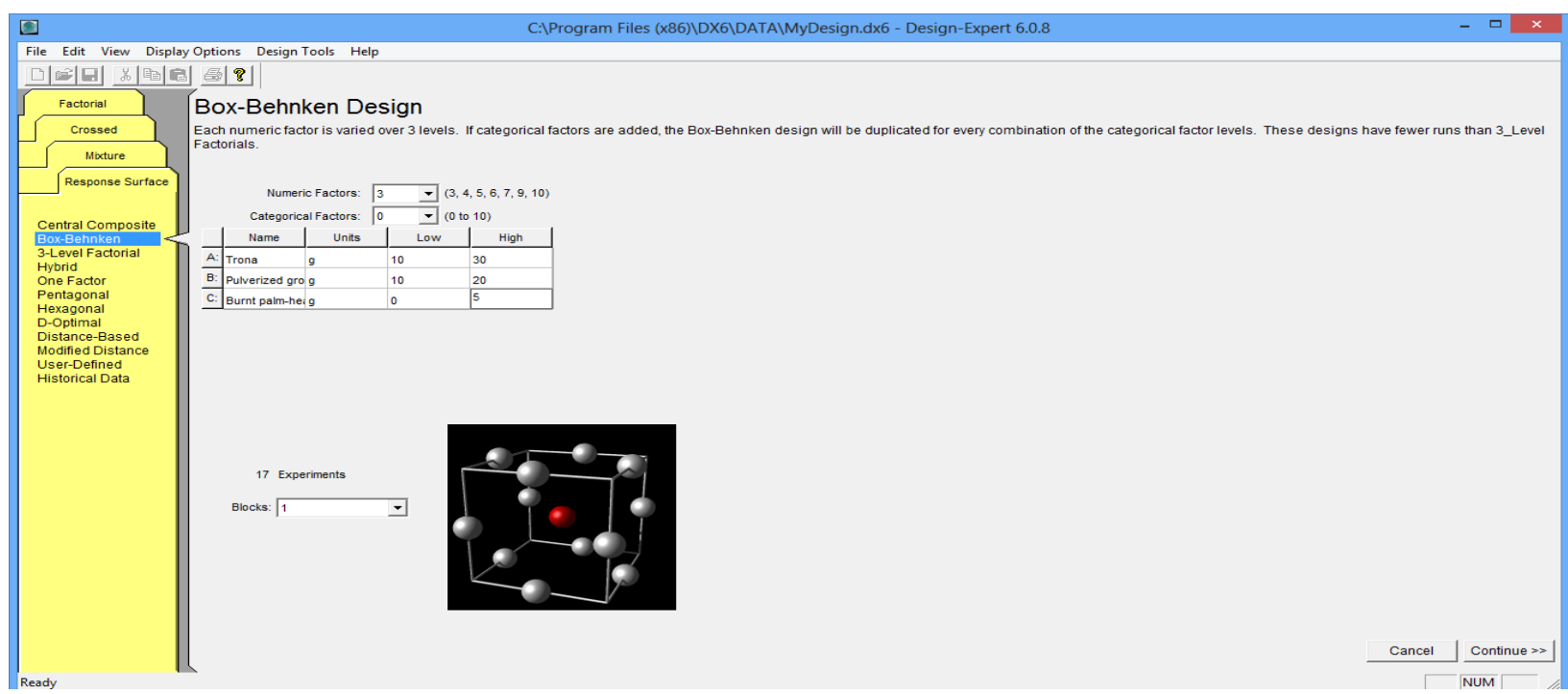

Figure 4.Box-Behnken window showing independent variables 


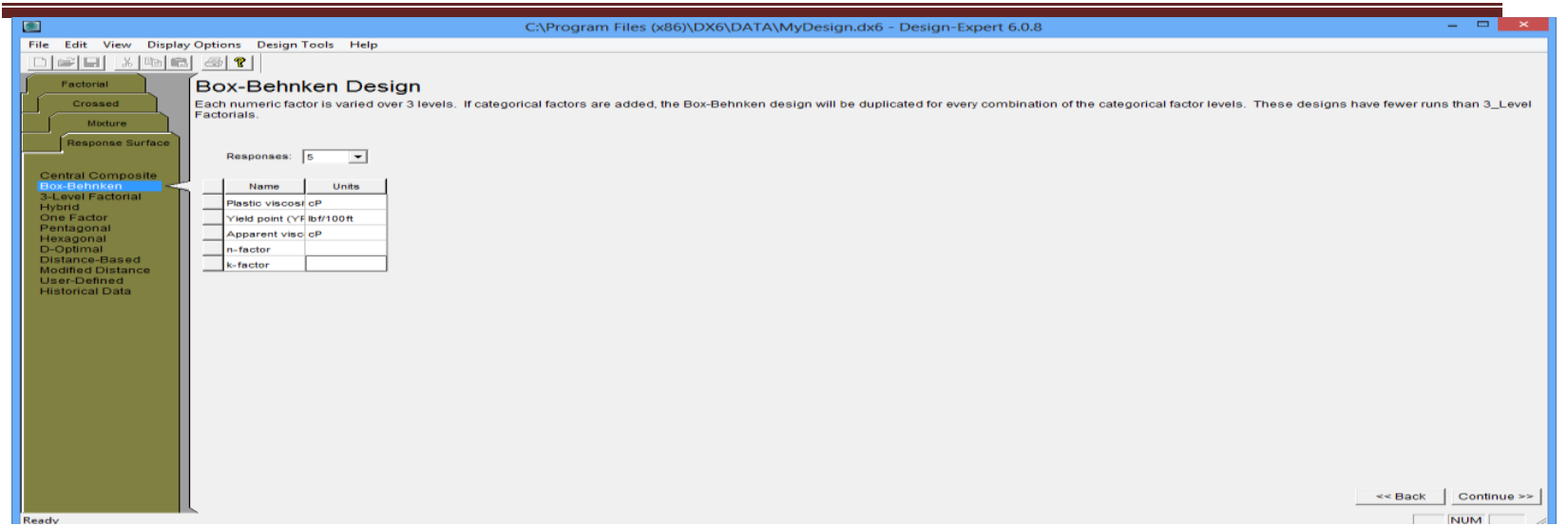

Figure 5. Box-Behnken design window showing five responses

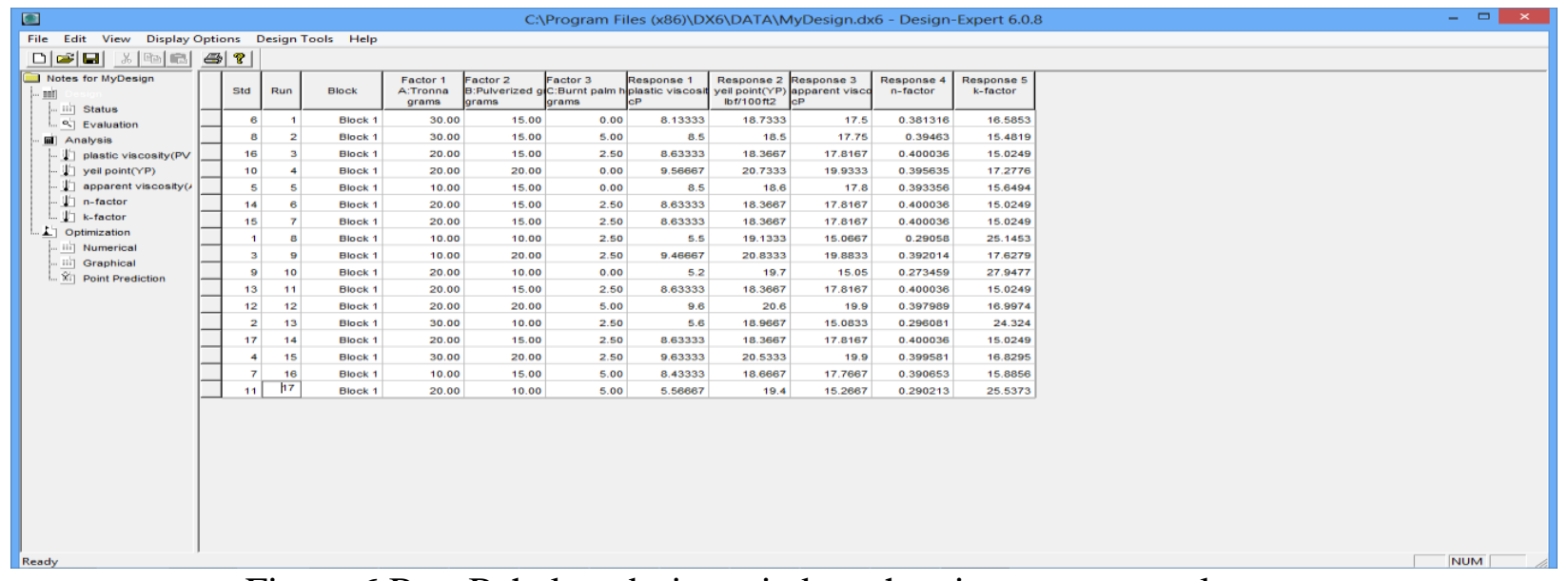

Figure 6.Box-Behnken design window showing response values

\section{RESULTS AND DISCUSSION}

Table 3 presents summary of rheological properties for the produced drilling mud.

Table 3. Rheological properties of the produced drilling mud

\begin{tabular}{ccccll}
\hline Runs & PV(cP) & YP(lbf/100ft $\left.\mathbf{~}^{\mathbf{}}\right)$ & AV $(\mathbf{c P})$ & n factor & k factor \\
\hline 1 & 9.60 & 20.60 & 19.90 & 0.40 & 361.35 \\
2 & 8.50 & 18.60 & 17.80 & 0.39 & 315.02 \\
3 & 9.63 & 20.53 & 19.90 & 0.40 & 364.55 \\
4 & 8.63 & 18.37 & 17.82 & 0.40 & 327.21 \\
5 & 9.47 & 20.83 & 19.88 & 0.39 & 349.29 \\
6 & 9.57 & 20.73 & 19.93 & 0.40 & 357.26 \\
7 & 8.50 & 18.50 & 17.75 & 0.39 & 316.37 \\
8 & 5.60 & 18.97 & 15.08 & 0.30 & 155.69 \\
9 & 5.50 & 19.13 & 15.07 & 0.29 & 150.85 \\
10 & 5.20 & 19.70 & 15.05 & 0.27 & 137.04 \\
11 & 5.57 & 19.40 & 15.27 & 0.29 & 152.54 \\
12 & 8.30 & 19.03 & 17.82 & 0.38 & 296.65 \\
13 & 8.13 & 18.73 & 17.50 & 0.38 & 289.72 \\
14 & 9.87 & 20.17 & 19.95 & 0.41 & 386.31 \\
15 & 8.43 & 18.67 & 17.77 & 0.39 & 309.76 \\
\hline
\end{tabular}


In Table 3, the rheological properties for the produced drilling mud (i.e. plastic viscosity $(\mathrm{PV})$, yield point (YP), apparent viscosity (AV), n- factor and k- factor) were determined by substituting the dial reading data into EEquations (1) - (5) as stated earlier. It can be seen that PV for runs 8, 9, 10 and 11 were 5.6, 5.5, 5.2 and 5.57 centi poise, $\mathrm{cP}$, respectively, which fell below the API numerical value standard for drilling mud (i.e. 8 - $10 \mathrm{cP}$ ), while the other runs fell within the API numerical value standard for drilling mud. The low PV may be attributed to low amounts of viscosifiers that were added (i.e. pulverized ground nut husk and starch). Therefore, other rheological properties such as YP and AV were also affected, since they are dependent on PV (Mbagwu et al., 2013). This observation is in agreement with the finding of Olatunde et al. (2012), who observed that additives such as polyanionic cellulose and Gum Arabic improves the rheological properties of a local bentonitic clay material to API numerical value standard for drilling mud. It can also be seen that $n$ - power factor was found to be within the range of $0.27-0.41$ - the API standard is "less than 1". The n-power also implied that the fluid obeys Bingham plastic fluid since the values were less than 0.5. In addition, the $\mathrm{k}$-factor which is directly proportional to fluid effective viscosity was found within the range of 137.09 - 309.76. Increased value of k-factor implies decreased cutting concentration (Caen et al., 2013). The value for k-factor is thus far above the API standards for drilling mud.

The results for optimum properties found from the Box-Behnken technique is presented in Table 4.

Table 4. Optimal results for rheological properties using Box-Behnken design

\begin{tabular}{|c|c|c|c|c|c|c|c|c|c|}
\hline $\begin{array}{l}\text { SS/ } \\
\text { N. }\end{array}$ & $\begin{array}{c}\text { Trona } \\
(\mathrm{g})\end{array}$ & $\begin{array}{l}\text { PVG } \\
\mathrm{H} \\
(\mathrm{g})\end{array}$ & $\begin{array}{l}\text { BPHS } \\
\text { P } \\
(\mathrm{g})\end{array}$ & $\begin{array}{l}\text { PV } \\
\text { (cP) }\end{array}$ & $\begin{array}{l}\text { YP } \\
\left(\mathrm{lbf} / 100 \mathrm{ft}^{2}\right)\end{array}$ & $\begin{array}{l}A V \\
\text { (cP) }\end{array}$ & $\begin{array}{l}n- \\
\text { factor }\end{array}$ & $\begin{array}{l}\text { k- } \\
\text { factor }\end{array}$ & Desirability \\
\hline 1 & 10.00 & 18.58 & 5.00 & 9.26 & 20.00 & 19.26 & 0.40 & 16.32 & 0.434 \\
\hline 2 & 21.87 & 14.20 & 0.00 & 8.00 & 18.63 & 17.32 & 0.38 & 17.35 & 0.428 \\
\hline 3 & 24.72 & 14.30 & 0.00 & 8.00 & 18.64 & 17.32 & 0.38 & 17.26 & 0.428 \\
\hline 4 & 20.61 & 14.16 & 0.00 & 8.00 & 18.63 & 17.31 & 0.38 & 17.37 & 0.427 \\
\hline 5 & 20.32 & 14.16 & 0.00 & 8.00 & 18.63 & 17.31 & 0.38 & 17.37 & 0.427 \\
\hline 6 & 10.01 & 14.12 & 5.00 & 8.00 & 18.60 & 17.30 & 0.38 & 16.78 & 0.388 \\
\hline 7 & 10.00 & 19.07 & 4.90 & 9.32 & 20.27 & 19.45 & 0.40 & 16.76 & 0.385 \\
\hline 8 & 10.51 & 14.09 & 5.00 & 8.00 & 18.59 & 17.30 & 0.38 & 16.79 & 0.380 \\
\hline 9 & 10.00 & 14.10 & 4.92 & 8.00 & 18.58 & 17.29 & 0.38 & 16.75 & 0.380 \\
\hline
\end{tabular}

Table 4 presents summary of experimental results for optimum rheological properties using Box-Behnken design. It can be seen that nine optimal solutions were found, with decreasing desirability factor (i. e. $0.43-0.38$ ). This implies that the highest desirability factor depicts the most optimal independent variables, which are trona, pulverized groundnut husk (PVGH) and burnt palm-head sponge powder (BPHSP) and its corresponding rheological properties (i.e. plastic viscosity (PV), yield point (YP), apparent viscosity (AV), n- factor and $\mathrm{k}$ - factor). The optimal independent variables were found to be 10.0, 18.58 and $5.0 \mathrm{~g}$ respectively. While the corresponding optimal rheological properties were $9.26 \mathrm{cP}, 20.0 \mathrm{lbf} / 100 \mathrm{ft}^{2}, 19.26 \mathrm{cP}, 0.40$ and 16.32 respectively.

\section{CONCLUSION}

Optimization for production of water-based drilling mud from specific additives using BoxBehnken design was conducted. The Box-Behnken design revealed that optimal independent variables, which are the additives (i.e. trona, pulverized ground nut husk and burnt palm head sponge powder) were $10.0 \mathrm{~g}, 18.58 \mathrm{~g}$ and $5.0 \mathrm{~g}$ respectively and the corresponding 
rheological properties (i.e. plastic viscosity (PV), yield point (YP), apparent viscosity (AV), $\mathrm{n}$ - factor and k- factor) were $9.26 \mathrm{cP}, 20.0 \mathrm{lbf} / 100 \mathrm{ft}^{2}, 19.26 \mathrm{cP}, 0.40$ and 16.32 respectively. In view of the results obtained, it was found that the produced mud obeys Bingham plastic fluid model and thus can be used as a standard drilling mud in the petroleum industry.

\section{REFERENCE}

1. Adekile, F. H. (2010). Applied Drilling Engineering, (2nd ed.), Society of Petroleum Engineers. Richardson, Texas, USA.

2. Annudeep, S. D. (2012). Rheological properties and corrosion characteristics of drilling mud Additives. A Master's thesis Department of Petroleum Engineering, Dalhousie University Halifax, Novia Scotia.

3. American Petroleum Institute (API).(2000).Specification for drilling - fluid materials Specification 13. American Petroleum Institute, Washington, DC. 47 - 57222.

4. Caenn, R., Darley, H. C., \& Gray, G. R. (2013). Composition and Properties of Drilling and Completion Fluids. Gulf Professional Pub., 2nd Ed., London, 60 - 80.

5. Dagde, K. K., Nmebgu, C. and Godwin, J. (2014). Drilling fluid formulation using cellulosegenerated from ground nut husk. International Journal of advancement in research,3(1), $27-33$.

6. Growcock, F., \& Harvey, T. (2012). Drilling Fluids. In ASME Shale Shaker Committee, DrillingFluids Processing Handbook. Elsevier, 2, 120 - 135.

7. Joel, O. F, Durueke, U. J. and Nwokoye, C. U. (2012). Effect of KCL on Rheological Properties of Shale Contaminated Water-Based Mud. Global Journal of Researches in Engineering, 12(1), $222-227.77-85$.

8. Mbagwu, C. P., Dosunmu, A. and Ajienka, J. A. (2013). Analysis of flow properties of bentonite clay for drilling fluid production. Journal of research and production. 5 (2), 1- 4.

9. Olatunde, A. O., Usman, M. A., O. A. and Adeosun, T. A. (2012). Improvement of rheological properties of drilling fluid using locally based materials. Petroleum \& Coal 54(1), 65-75,

10. Okorie, O. M. (2009). Modification of drilling fluid $\mathrm{pH}$ with local Nigerian additives.Petroleum Technology Development Journal, 1(6), 12 - 17.

11. Oyegoke, T. (2011). Optimization for the production of water-based drilling mud from local clay, B.Eng Research project, Department of chemical engineering, FUT Minna, Nigeria.

12. Ogbonna, F. J. (2010). Design and Field Application of Drilling Cementing and Stimulation Fluids, Chi Ikoku Petroleum Engineering Series, 20-22, 35-42. 